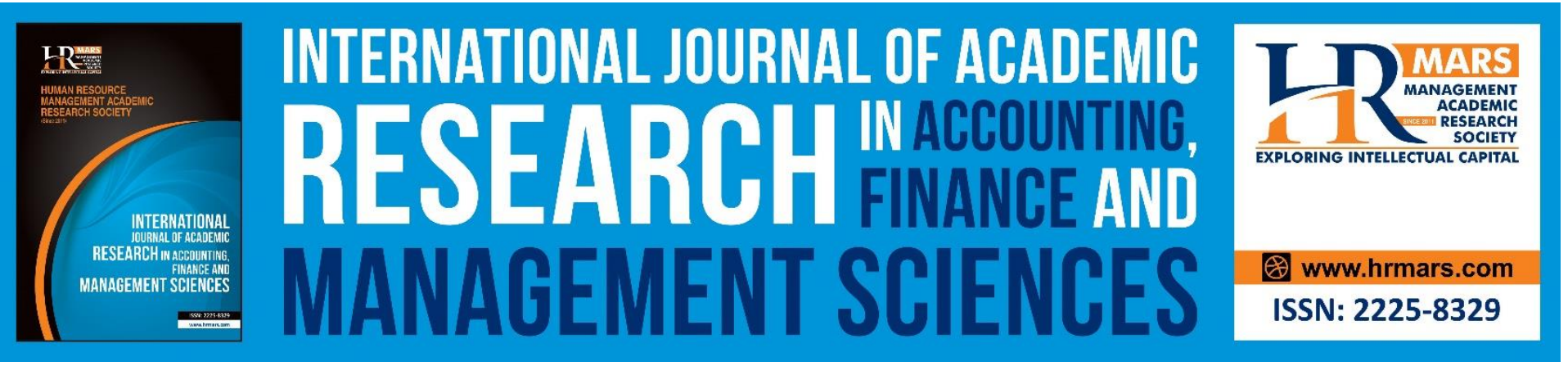

\title{
The Moderating Effect of Individual Taxpayers' Education Level on Ethical Perception and Tax Compliance Behaviour in Peninsular Malaysia
}

\author{
Swee Kiow Tan, Claudia Lau, Aza Azlina Md Kassim, Mohd Fuad Mohd \\ Salleh
}

To Link this Article: http://dx.doi.org/10.6007/IJARAFMS/v11-i1/8857

DOI:10.6007/IJARAFMS /v11-i1/8857

Received: 11 January 2021, Revised: 05 February 2021, Accepted: 28 February 2021

Published Online: 16 March 2021

In-Text Citation: (Tan et al., 2021)

To Cite this Article: Tan, S. K., Lau, C., Kassim, A. A. M., \& Salleh, M. F. M. (2021). The Moderating Effect of Individual Taxpayers' Education Level on Ethical Perception and Tax Compliance Behaviour in Peninsular Malaysia. International Journal of Academic Research in Accounting Finance and Management Sciences, 11(1), 166-182.

Copyright: () 2021 The Author(s)

Published by Human Resource Management Academic Research Society (www.hrmars.com)

This article is published under the Creative Commons Attribution (CC BY 4.0) license. Anyone may reproduce, distribute, translate and create derivative works of this article (for both commercial and non-commercial purposes), subject to full attribution to the original publication and authors. The full terms of this license may be seen

at: http://creativecommons.org/licences/by/4.0/legalcode

Vol. 11, No. 1, 2021, Pg. 166 - 182

http://hrmars.com/index.php/pages/detail/IJARAFMS

JOURNAL HOMEPAGE

Full Terms \& Conditions of access and use can be found at http://hrmars.com/index.php/pages/detail/publication-ethics 


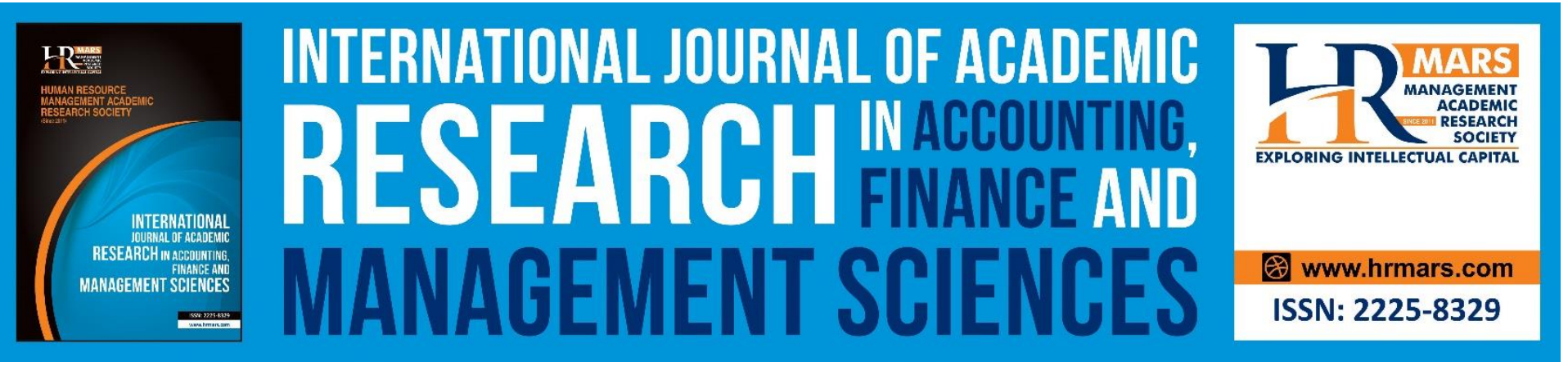

\title{
The Moderating Effect of Individual Taxpayers' Education Level on Ethical Perception and Tax Compliance Behaviour in Peninsular Malaysia
}

\author{
${ }^{1}$ Swee Kiow Tan, ${ }^{1}$ Claudia Lau, ${ }^{2}$ Aza Azlina Md Kassim, ${ }^{3}$ Mohd Fuad \\ Mohd Salleh \\ ${ }^{1}$ Faculty of Business and Finance, Universiti Tunku Abdul Rahman, Perak Campus, Jalan Universiti, \\ Bandar Barat, 31900 Kampar, Perak, Malaysia, ${ }^{2}$ School of Economics and Management, Xiamen \\ University Malaysia, 43900 Sepang, Selangor, Malaysia, ${ }^{3}$ Kolej Universiti Islam Zulkifli Muhammad, \\ 68100 Batu Caves, Selangor, Malaysia. \\ Email:sktan@utar.edu.my
}

\begin{abstract}
Tax revenue is a main source of income to government and is used for various public services and essentials. Taxes generally are perceived as a burden to taxpayers, so tax evasion is a universal phenomenon that governments facing in the world. Malaysia is in the fiscal deficit situation and it became worse during the Covid-19 pandemic. It is important to increase tax revenue as it would help to reduce the fiscal deficit. This study looks into how ethical perception of individual taxpayers to be influenced by their education level and hence further influence their tax compliance behaviour. The researcher used cross-sectional survey design to collect data at one point in time. This study using Statistical Package for the Social Science (SPSS) version 21 to analyse the data in order to obtain meaningful information. Based on 606 respondents in Peninsular Malaysia, the study indicates that ethical perception has a positive significance impact on tax compliance behaviour. The results also highlight a significant positive relationship between ethical perception and tax compliance behaviour when moderated by education level. It means education level will enhance ethical perception of individual taxpayers, hence they will be more compliant. Based on this findings, government can improve further their existing policies to make sure high tax compliance in future.
\end{abstract}

Keywords: Education Level, Ethical Perception, Tax Compliance Behaviour.

\section{Background of the Study}

Some researchers (Galib, Indrijawati \& Rasyid, 2018) highlight that governments around the world seeking revenue for public needs, so tax compliance is a main concern for most of the countries. Tax revenue is a main source of income to government in both developing and developed countries. Tax revenue raised is used for various crucial services and public essentials. Taxes generally 
INTERNATIONAL JOURNAL OF ACADEMIC RESEARCH IN ACCOUNTING, FINANCE AND MANAGEMENT SCIENCES

Vol. 11, No. 1, 2021, E-ISSN: 2225-8329 @ 2021 HRMARS

are perceived as a burden to taxpayers, so tax evasion is a universal phenomenon that governments facing in the world. Malaysia has introduced self-assessment (SA) for corporate taxpayers since year 2001 and in 2004 for all other taxpayers comprising individuals. Hence, it is taxpayers' responsibility to assess their tax liability, which means that they should have some tax knowledge to handle it. According to Singh (2013) tax returns are not subject to thorough technical scrutiny by the IRB under SA. This change was aimed at get rid of the increasing workload of the IRB to let the IRB to focus on areas with high tax risks and revenues.

Under SA, Inland Revenue Board (IRB) no more issuing notice of assessment. The tax returns submitted by taxpayers are considered to be their notice of assessment. High levels of voluntary compliance by taxpayers is essential for an effective SA system, but non-compliance behaviour is the problem that has been highlighted. The Inland Revenue Board (IRB) has identified 79,786 individuals, companies, organisations, cooperatives who have yet to pay tax (The Star Online, 2018). The Inland Revenue Board implements penalties and enforcement actions i.e. the economic deterrence strategies (Singh, 2013), if taxpayers do not submit a correct tax return on time. Malaysia is in the fiscal deficit situation since 1998. The situation become worse and its fiscal deficit become deeper during the Covid-19 pandemic. It is important to increase tax revenue as it would help to reduce the fiscal deficit.

Using quantitative approach, this study has two main objectives;

i) to examine the direct effect of ethical perception on tax compliance behaviour of individual taxpayers and

ii) to determine the moderating effect of education level on the relationship between ethical perception and tax compliance behaviour of individual taxpayers.

The paper is organized as follows. In the following section, the predictions on the influence of ethical perception and education level on tax compliance behaviour are presented. The third section presents the research methodology followed by the research findings in the fourth section. Finally, the discussion and conclusion of the study is presented in the last section.

\section{Previous Literature}

Ethics imply a moral mind-set which directs the human actions as well as businesses, and shapes a part of the attitude related to the behaviours of people (Al Zeer, Alkhatib \& Alshrouf, 2019). Previous researchers Song and Yarbrough (1978) established that education level is positively associated to taxpayers' tax ethic. This result is further supported by other researchers. Their findings showing that taxpayer ethics increase with education (McGraw \& Scholz, 1988; Christensen Weihrich \& Newman, 1994; Eriksen \& Fallan, 1996). According to the researchers (Loo, McKerchar \& Hansford, 2009), education level influences individuals' tax knowledge acquired. Therefore, subsequently influencing their attitudes towards tax and then affecting their compliance behaviour. Especially for those salary and wage earners. Some researchers (Alasfour, Samy \& Bampton, 2016) further confirm that educational level play an important character in determining the level of tax morale. The recent research highlighted that education on taxation has had a positive influence on students' tax attitudes. Hence, it is important to increase the tax ethics in so

ciety, giving education on taxation as students will be future taxpayers, their attitude towards taxation is very important because it reflects their tax ethics (Zeynalova, 2019). 
On the other hand, a study in Iran indicates that those with higher levels of education are having lower tax morale. This finding confirms that they may more aware of government inefficiencies and have some criticisms on how government redistributed the tax being collected. As a result, higher education look like to be the main factor of lower tax morale (Hosseini Kondelaji, Sameti, Amiri \& Moayedfar, 2016). A different result is obtained by this recent research. The researchers (Noor \& Abd Razak, 2019) highlight that they are lacked of study on the students' ethical perception towards tax evasion irrespective of the fact that they will be the potential taxpayers. Therefore, this study investigate the perception of accounting and non-accounting students towards the ethics of tax evasion in Malaysia. The results point out that there are no significant differences between fields of study, education level for ethical perception on tax evasion. The results are in conformity with finding of Harun, Abu Bakar and Tahir (2011).

The researchers (Eriksen \& Fallan, 1996) look at the impact of specific tax knowledge on attitudes towards taxation. The study highlights that specific tax knowledge has positive significant changes in attitude to one's own tax evasion. Taxpayers' behavioural intentions are usually influenced by their ethics or morals (Trivedi et al., 2005; Henderson \& Kaplan, 2005). Malaysian taxpayers know that they are legally and morally to pay tax and submit tax returns (Ho et al., 2006). They also think that should penalised those who know their tax obligations but do not fulfil it, as this is consider unethical and immoral (Kasipillai et al., 2003). The researcher Singh (2013) also indicates that taxpayers with higher fiscal knowledge are tend to be higher in tax ethics compared to those with lower fiscal knowledge. According to researchers (Loo, Evans \& McKerchar, 2012), it seems that Malaysian taxpayers are having high ethics and their compliance behaviour is influenced by their tax knowledge. Whereas researcher (Pratama, 2017) indicates that students' perceptions of tax avoidance does not significantly influence by tax knowledge.

In addition, Lago-Peñas and Lago-Peñas (2010) highlight that education shows negative influence to tax morale and hence negative significant relationships to tax compliance as well. The past researchers highlight the association between education and attitude to tax evasion is unclear. The results are not consistent when compare the association between educational level and attitude to tax evasion in Brazil, Russia, China, India, USA and Germany (McGee \& Ross, 2014). This may due to it is affected by other demographics factors such as age, gender, income level and occupation. Thus, more research is needed to investigate further.

According to past researchers (Ho et al., 2006; Kasipillai et al., 2003), both level of tax ethics and level of voluntary compliance are high for individual taxpayers in Malaysia. These are the main reasons for the success of Malaysia's self-assessment system. The researchers (Blanthorne \& Kaplan, 2008) also indicate that ethical beliefs influence compliance behavior. Other researchers Chan, Troutman and O'Bryan (2000) conduct a research to make a comparison on compliance behavior between Hong Kong and US taxpayers. They highlight that age and education are the main factors to influence US respondents' decision to comply with tax laws, so consequently influence their attitude and moral development in a positive relationship. On the other hand, Hong Kong respondents have indicated negative relationship between education, moral development, attitude and compliance. The recent 
INTERNATIONAL JOURNAL OF ACADEMIC RESEARCH IN ACCOUNTING, FINANCE AND MANAGEMENT SCIENCES

Vol. 11, No. 1, 2021, E-ISSN: 2225-8329 @ 2021 HRMARS

research conducted in Akwa Ibom State also indicates that there is no significant influence of taxpayers' ethics on voluntary compliance in Self-Assessment System (Okon \& Israel, 2020).

Past researchers recommend that positive relation exist between ethical belief of individuals and their tax compliance level. In addition, taxpayer will be more compliance when they have a stronger moral belief that tax evasion is unethical (Ho \& Wong, 2008). Similarly, previous researchers (Simmons \& Cheng, 1996), also discover that tax evasion is considered acceptable by Hong Kong citizens. Therefore, it is important to educating the public on tax compliance. The Hong Kong government supported the idea to enhance taxpayers' compliance with tax laws through strengthened the tax education. Past studies (Alm \& Torgler, 2011) claim that there is evidence that ethics among individuals are different and these differences significantly influence their compliance decisions. Other researcher (Cahyonowati, 2011) further support that those with higher ethic taxpayers have better tax compliance.

Chinese individual taxpayers' ethics in China are greatly influenced by their strong belief in Confucianism, especially filial piety (Ho, Ho, \& Young, 2013). The findings further supported by researchers (Young, Wong \& Kwok, 2016). The researchers highlighted that Confucianism and Legalism influence both Chinese social and individual ethical beliefs, hence nurture greater tax compliance in China. It is important to base on legalism to design the tax regulations, prompting individuals to fulfil with their tax responsibilities. An individual's ethical beliefs is closely related to their tax compliance. The reason is their ethicality influences their willingness to fulfil with their tax responsibilities.

The researcher (Nsor-Ambala, 2016) conducts a study on the correlation between ethical orientation and tax compliance. The researcher discovers that ethical individuals are more affected by tax rate and withholding positions and usually more tax compliant than unethical individuals as well. Individuals with higher tax moral and hence more comply with tax obligations are going to generate more tax revenue to government. Therefore government has enough resources to enhance the living standard of the societies. The researchers conduct the study to survey the moral of business income tax payers and their tax compliance behaviour in Ethiopia. The result indicates that the association between moral of tax payers and their compliance behaviour is significant (Redae \& Sekhon, 2017). Similarly, the recent study also highlights that tax morale has a positive relationship with the tax compliance level, i.e. higher tax morale will lead to higher level of tax compliance among selfemployed in Malaysia (Ghani, Abd Hamid, Sanusi \& Shamsuddin, 2020).

Educated taxpayers are more knowledgeable on tax law and fiscal relations than uneducated taxpayers. Previous research conducted by Birch, Peters \& Sawyer (2003) stated that those higher education students in New Zealand with better taxation knowledge are least involved in understating taxable income. In other research conducted in Malaysia regarding the effect of education on undergraduate students' tax compliance, Kasipilllai, Aripin and Amran (2003) also find significant association between education and tax compliance. As a result, taxpayers with higher education are considered more alert on the services and benefits furnished by the government (Torgler \& Murphy, 2004). Taxpayers who are highly educated have to be more critical of how the government uses tax revenue and identify the wastage. Moreover, they can understand better the chances for tax evasion 
INTERNATIONAL JOURNAL OF ACADEMIC RESEARCH IN ACCOUNTING, FINANCE AND MANAGEMENT SCIENCES

Vol. 11, No. 1, 2021, E-ISSN: 2225-8329 @ 2021 HRMARS

and tax avoidance (Torgler \& Schaltegger, 2005). Therefore they can make a better decision, whether is a gain or a loss when payment of taxes. Past researcher (Kornhauser, 2007) highlights that education has influence on tax compliance. Similar result also generate by Verboon and van Dijke (2007). Further studies by researchers (Torgler, Demir, Macintyre \& Schaffner, 2008, Torgler, 2012) also find that those taxpayers with higher education are more compliant than taxpayers without formal education. In addition, taxpayers with highly education can receive good income easily in legal or formal activities and consequently are not to conduct tax evasion (Frey, 2009).

In the study on Australian tertiary students, Devos (2005) find that those respondents have education background has significant influence on their attitude towards tax evasion. The similar outcome is stated by Devos (2008) and Gupta (2009). Some researchers argue that tax compliance is influenced by different types of tax education. To discover this empirical issue, the researchers (Wong \& Lo, 2015) explore in what way various types of tax education influence Hong Kong students' tax compliance decisions. The results propose that those undergraduate students have taken general tax education are significantly improved in their sales tax compliance, and for those postgraduate students who have taken a technical tax course are significantly improved in their income and sales tax compliance. A few researchers highlight that students are future taxpayers, so schools should introduced tax education to students at early stage as it be able to help and affect their attitude to tax compliance (Eiya, llaboya \& Okoye, 2016). Most of the investigations including Ameyaw and Dzaka (2016) and Daba (2017) discover that education level is positively related to taxpayer compliance.

On the other hand Groenland and van Veldhoven (1983) warned that those can understanding (education) tax laws better are less compliant due to know the loopholes to avoid taxes. This is confirmed by Chan et al. (2000). Another researcher, Mustapha (2017) finds that taxpayers' level of education has opposite significant relationship with their tax compliance. Due to that, the researcher recommends the government to include tax education in its school curriculum, to educate the potential taxpayers on the benefit of tax payment. This will enhance their level of tax compliance. Recent evidence suggests that educational level of tax payers is negatively and significantly influences their tax compliance. The result of this study highlights that higher level of education leading to lower level of tax compliance, so resulting to higher tax evasion (Shiferaw \& Tesfaye, 2020).

Different from other researches, Schuetze (2002) did not discover clear relation between the level of education and tax noncompliance among self-employed in Canada. Another study also determines that there are no differences between educated and non-educated taxpayers when they submit their tax returns (Ejakait, 2011).

Roth et al. (1989) define tax compliance as filing all required tax returns accurately in accordance with the tax law and at the proper time. Previous study has reported the fairness of the tax system may influence a taxpayers' compliance behaviour. The taxpayers may not be willing to comply if they see the tax system is unfair. This be influenced by on their level of experience and knowledge towards the tax system (Mohd, Mohd \& Wan, 2013). The researchers (Jayawardane \& Low, 2016) highlight that tax compliance decision is influenced by high tax rate, complex and unfair tax system. Besides it also influenced by insufficient tax audits, low probability of detection, weak enforcement action of 
INTERNATIONAL JOURNAL OF ACADEMIC RESEARCH IN ACCOUNTING, FINANCE AND MANAGEMENT SCIENCES

Vol. 11, No. 1, 2021, E-ISSN: 2225-8329 @ 2021 HRMARS

the Inland Revenue Department and government spending. In contrast, Alabede (2014) indicates gender, educational background and religious faith do not have significant impact on tax compliance behaviour in Nigeria. Similarly, the researchers (Defitri \& Fauziati, 2018) also highlight that age and education do not have influence on tax compliance.

According to researchers (Ho \& Wong, 2008), taxpayers might be more compliance through a stronger enforcement. But, another researcher Cahyonowati's (2011) highlights that ethics show a significant effect in increasing tax compliance compared to fines and tax sanctions. In addition, taxpayers' compliance is affected by the ethical dimension, justice, an equivalent economic exchange, and trust (Alm \& Torgler, 2011). In another study, Oladipupo and Obazee (2016) examine the small and medium enterprises in Nigeria, regarding the effects of tax payers' knowledge and penalties on tax compliance. The outcomes highlight that tax knowledge has a positive significant influence on tax compliance, whereas tax penalty has insignificant positive influence on tax compliance. As a result, the researchers recommend that government should increase public's tax knowledge and to include tax education in school curricula.

Taxpayers' education level influence their job selection and consequently their income level and financial position. Therefore subsequently influence taxpayers' attitudes to tax, and influencing taxpayers' compliance behaviour directly as well. (Loo, McKerchar \& Hansford, 2009). Other researchers (Marziana, Mohamad, Orkhazimah \& Mohmad, 2010) further confirm that taxpayers with high income level be likely to be more compliant than those lower income taxpayers. On the other hand, researchers (Loo, McKerchar \& Hansford, 2009) also indicate that enhancement in taxpayers' tax knowledge would have a negative association with some taxpayers' attitudes to tax administration, their perceptions of the Inland Revenue Board of Malaysia officers' duty and their perceptions of the fairness of the tax system. Due to that, improvement of tax knowledge does not necessarily increase some respondents' attitudes to taxation.

Various factors significantly affect tax compliance behavior such as perception on equity and fairness of the tax system; perception on government spending; penalties; individual financial constraint; changes on current government policies; and social norms. On the other hand, gender and possibility of being audited have no significant influence on tax compliance behavior. The results also indicate that elderly individual will be not so compliant if there is no equity and fairness in the tax system and any unfavorable changes in government policy on basic needs such as fuel prices, electricity and water rates (Tehulu \& Dinberu, 2014). Previous researchers also recommend that family members and close friends can affect an individual taxpayer's compliance behaviour (Ho, Ho, \& Young, 2013). Furthermore, researcher (Abdullahi, 2017) also highlights that perceived audit effectiveness, perceived tax service quality, perceived citizen engagement and perceived social norm are all examine to have a significant positive association with tax compliance behavior.

The researcher (Mulugeta, 2018) reveals that poor services of tax authority, poor perception to government spending and lower level of tax knowledge are affect individual taxpayers' tax compliance behaviour. So it is necessary to improving tax knowledge and increasing the attitude of government spending. In another study, the government's transparency when governing the tax system and government's finance has positive relationship with taxpayers' trust and ethical 
INTERNATIONAL JOURNAL OF ACADEMIC RESEARCH IN ACCOUNTING, FINANCE AND MANAGEMENT SCIENCES

Vol. 11, No. 1, 2021, E-ISSN: 2225-8329 @ 2021 HRMARS

behaviour. Consequently it will influence individual taxpayer's compliance in Surabaya (Mangoting, Tangkelobo \& Sina, 2019). Other factors such as public governance quality to effect tax compliance in relation to control of corruption and government effectiveness in Nigeria. Therefore, the researcher recommends that there should be great improvement in government effectiveness by providing quality infrastructure; quality educational system and quality health service to improve the tax compliance of individual taxpayers; and also, should give priority to control corruption in the state (Salam, 2019).

Tax knowledge is the taxpayers' level of awareness to tax regulation. Hence, taxpayers become abreast with tax regulation and other tax related information (Hasseldine et al., 2009). Taxpayers' tax knowledge learned from general education is the main factor for them to understand those requirements relating to filing procedures and registration. Taxpayers would fulfil their obligations and undoubtedly, they will perceive it is their national and civic responsibility to pay tax. Lumumba et al. (2010) show that, Small and Medium Enterprises (SMEs) did not fulfil their tax obligations for the reason that there are unable to understand tax law requirements in Kenya. The recent study conducted by researchers (Al-Ttaffi, Bin-Nashwan \& Amrah, 2020) show that tax knowledge influence tax compliance behaviour positively. Hence, the researcher advise government to improve tax knowledge of Yemen citizens which may increase their level of tax compliance. On the other hand, other researchers (Fauziati et al., 2016) discover that tax compliance is not influenced by tax knowledge.

Inconsistent results have been reported for the previous investigations on the effects of deterrent and social psychological factors on tax compliance. Hence, the recent researchers proposing that the mixed results might explain by a moderator. The recent researchers suggest the perceptions of corruption as moderator for the relationships between deterrent factors and tax compliance. In addition, the perceptions of corruption also as moderator for the effects of social psychological factors on tax compliance behaviour among SMEs in Uganda (Tusubira \& Mugarura, 2020). Based on the preceding literature review, the researcher recommend education level as moderator for this study. 
INTERNATIONAL JOURNAL OF ACADEMIC RESEARCH IN ACCOUNTING, FINANCE AND

MANAGEMENT SCIENCES

Vol. 11, No. 1, 2021, E-ISSN: 2225-8329 @ 2021 HRMARS

The research framework is presented in Figure 2.1.

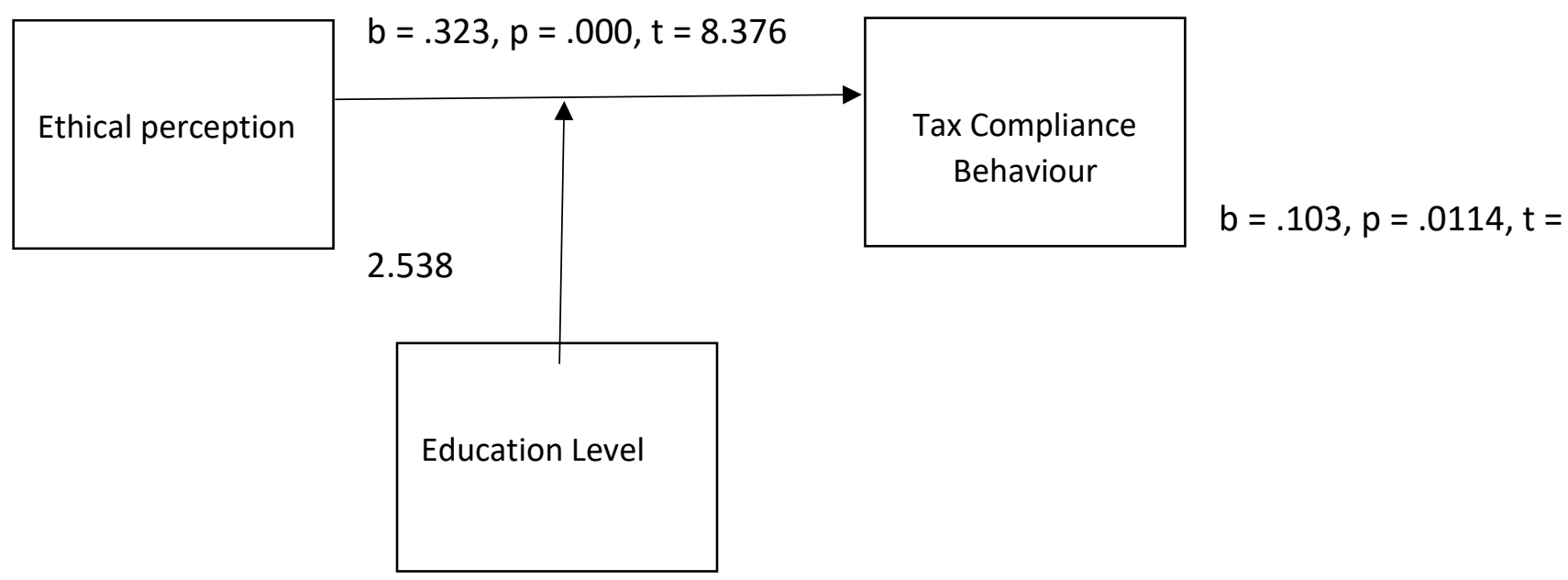

Figure 2.1 Research Framework for Moderating Effect of Education Level on the Relationship between Ethical Perception and Tax Compliance Behaviour of Individual Taxpayers in Peninsular Malaysia.

\section{Research Methodology}

The researcher used cross-sectional survey design to collect data at one point in time. In this research, a survey is a good procedure to be used. It is less expensive and faster way to collect data and they can reach a geographically dispersed population. Further, the researcher can canvass the respondents anonymously, without biasing their responses (Creswell, 2012). In this research, the researcher had chosen convenience sampling over other types of sampling as it is the best way of getting information quickly and efficiently (Sekaran \& Bougie, 2016). Convenience sampling is a nonprobability sampling technique and it is useful specifically when the population is very large (Etikan, Musa \& Alkassim, 2016), which is suitable for this research.

The population for the study consists of the whole group of individual taxpayers in Malaysia. This study presumed that workforces' gender ratio was same as the whole population. Out of 30.4 million population, 15.4 million (50.7\%) were males and 15.0 million (49.3\%) were females. In this condition, questionnaires will be distributed to males and females equally as the researcher intended to draw attention to a specific subgroup (gender) within the population. Sekaran \& Bougie (2016) suggest that for a total population of one million, the optimum sample size is 384 or $0.0384 \%$. Hence, by analysing the sample, this research should be able to draw conclusions that are generalizable to the population of interest (Sekaran \& Bougie, 2016).

With regards to data analysis, this study using Statistical Package for the Social Science (SPSS) version 21 to analyse the data in order to obtain meaningful information.

\section{Data Analysis}

In carrying out this study, a total of seven hundred (700) copies of the questionnaire were administered. However, out of these, 14 were incomplete, leaving six hundred and six (606) as usable 
INTERNATIONAL JOURNAL OF ACADEMIC RESEARCH IN ACCOUNTING, FINANCE AND MANAGEMENT SCIENCES

Vol. 11, No. 1, 2021, E-ISSN: 2225-8329 @ 2021 HRMARS

copies, representing $86.6 \%$ response rate. Demographic characteristics of the respondents are summarized in Table 4.1. Out of 606 respondents, 308 (51\%) of the respondents are male and 298 $(49 \%)$ of the respondents are female, which is similar to the existing population ratio. Number of respondents for Malay and Chinese are very close, i.e. 254 and 253 respectively, followed by Indian 96 and others 3. Most of the respondents are well educated, with a total of 253 (42\%) respondents have a degree or professional whereas 90 (15\%) have master or PhD qualifications. Besides, 136 (22\%) of the respondents have certificate or diploma and the balance of $127(21 \%)$ respondents are with SPM or STPM qualifications. Furthermore, most of the respondents worked in private sector 366 (60\%), followed by public sector 134 (22\%).

Table 4.1:

Demographic Characteristics of the Respondents

\begin{tabular}{lrrrrr}
\hline & Frequency & Percentage & & Frequency & Percentage \\
\hline Race: & & & Education level: & & \\
Malay & 254 & 41.9 & SPM/STPM & 127 & 21.0 \\
Chinese & 253 & 41.7 & Certificate/Diploma & 136 & 22.4 \\
Indian & 96 & 15.9 & Degree/Professional & 253 & 41.7 \\
Others & 3 & 0.5 & Master/PhD & 90 & 14.9 \\
& & & & & \\
Gender: & 298 & 49.2 & Work nature: & 134 & 22.1 \\
Female & 308 & 50.8 & Public & 366 & 60.4 \\
Male & & & Private & 96 & 15.8 \\
& & & Self-employed/Partner & 10 & 1.7 \\
\hline
\end{tabular}

Table 4.2 reports the descriptive statistics based on 606 individual taxpayers. The mean value for the determinants is between 2.500 to 3.065 , ranging from 1 to 5 . The standard deviation is in the range of 0.778 to 0.984 . Ethical perception is with the highest mean of 3.065 , followed by tax compliance behaviour (3.046) and education level (2.5). The findings reveal that it is ethical to understate the income if the government is not doing the right thing. In addition, tax compliance behaviour are affected by prices of basic goods but not influenced by probability of being audited, penalty and education level. 
INTERNATIONAL JOURNAL OF ACADEMIC RESEARCH IN ACCOUNTING, FINANCE AND

MANAGEMENT SCIENCES

Vol. 11, No. 1, 2021, E-ISSN: 2225-8329 @ 2021 HRMARS

Table 4.2

Descriptive Statistics

\begin{tabular}{lcccc}
\hline & Minimum & Maximum & Mean & Std. Deviation \\
\hline Education Level & 1.000 & 4.000 & 2.500 & 0.984 \\
Ethical Perception & 1.000 & 5.000 & 3.065 & 0.781 \\
Tax Compliance Behaviour & 1.000 & 5.000 & 3.046 & 0.778 \\
\hline
\end{tabular}

Table 4.3 showing the influence of ethical perception (EP) and education level on tax compliance behaviour (TCB) of individual taxpayers. The EP $(b=.323, p=.000)$ is significant and its coefficient is positive indicating that the greater the EP of individual taxpayers, the higher their TCB. But, individual taxpayers education level $(b=-.007, p=.810)$ seems to be unrelated to TCB. In other words, with ethical perception in the model, education level is not adding a substantial contribution to explaining tax compliance behaviour of individual taxpayers in Peninsular Malaysia.

Table 4.3

Regression Coefficient

\begin{tabular}{|c|c|c|c|c|c|c|}
\hline \multirow{2}{*}{\multicolumn{2}{|c|}{ Model }} & \multicolumn{2}{|c|}{$\begin{array}{l}\text { Unstandardized } \\
\text { Coefficients }\end{array}$} & \multirow{2}{*}{$\begin{array}{c}\text { Standardized } \\
\text { Coefficients } \\
\text { Beta }\end{array}$} & \multirow[t]{2}{*}{$\mathrm{t}$} & \multirow[t]{2}{*}{ Sig. } \\
\hline & & $B$ & Std. Error & & & \\
\hline \multirow{3}{*}{1} & (Constant) & 2.054 & .121 & & 16.941 & .000 \\
\hline & EP & .324 & .038 & .325 & 8.447 & .000 \\
\hline & (Constant) & 2.075 & .150 & & 13.833 & .000 \\
\hline \multirow{2}{*}{2} & EP & .323 & .039 & .324 & 8.376 & .000 \\
\hline & $\begin{array}{l}\text { Education } \\
\text { level }\end{array}$ & -.007 & .031 & -.009 & -.241 & .810 \\
\hline
\end{tabular}

By referring to Table 4.4, moderation is shown up by a significant interaction effect, $b=0.103, \mathrm{Cl}$ [0.023, 0.183], $t=2.54, p=0.0114$, indicating that the relationship between ethical perception and tax compliance behaviour is moderated by education level.

Table 4.4

(Partial) output of the PROCESS macro for the simple moderation model

\begin{tabular}{lcccccc}
\hline & coeff & $\mathrm{se}$ & $\mathrm{t}$ & $\mathrm{p}$ & $\mathrm{LLCl}$ & $\mathrm{ULCl}$ \\
\hline Constant & 3.0534 & .0300 & 101.8954 & .0000 & 2.9945 & 3.1122 \\
Ethical Perception & .3055 & .0390 & 7.8418 & .0000 & .2290 & .3820 \\
Education level & -.0122 & .0305 & -.3992 & .6899 & -.0722 & .0478 \\
Int_1 & .1033 & .0407 & 2.5383 & .0114 & .0234 & .1833 \\
\hline
\end{tabular}

To interpret the moderation effect the researchers examine the simple slopes (Aiken \& West, 1991), which are shown in Table 4.5. The output shows us the results of three models: the model for ethical perception as a predictor of tax compliance behaviour (1) when education levels are low, i.e. -0.9837; (2) at the mean value of education level, i.e. 0; (3) when the education levels are high, i.e. 0.9837. The researchers interpret these models by looking at the value of $b$, and its significance. The researchers interpret the three models as follows: 
INTERNATIONAL JOURNAL OF ACADEMIC RESEARCH IN ACCOUNTING, FINANCE AND MANAGEMENT SCIENCES

Vol. 11, No. 1, 2021, E-ISSN: 2225-8329 @ 2021 HRMARS

(1) When education levels are low, there is a significant positive relationship between ethical perception and tax compliance behaviour, $b=0.204,95 \% \mathrm{Cl}[0.085,0.323], t=3.37, p=0.008$.

(2) At the mean value of education levels, there is a significant positive relationship between ethical perception and tax compliance behaviour, $b=0.306,95 \% \mathrm{Cl}[0.229,0.382], t=7.84, p<0.001$.

(3) When education levels are high, there is a significant positive relationship between ethical perception and tax compliance behaviour, $b=0.407,95 \% \mathrm{Cl}[0.307,0.507], t=8.02, p<0.001$.

These results indicate that the relationship between ethical perception and tax compliance behaviour really appears in individual taxpayers with various stages of education levels. It means by using education level as moderator, it still shows positive relationship but the significant values have been changed from stronger to the weaker position (from .000 change to .0114).

Table 4.5:

Output of the PROCESS macro for testing the conditional effect of $X$ on $Y$ in the values of the moderating variable

\begin{tabular}{ccccccc}
\hline Education level & Effect & $\mathrm{se}$ & $\mathrm{t}$ & $\mathrm{p}$ & $\mathrm{LLCl}$ & $\mathrm{ULCl}$ \\
\hline-.9837 & .2039 & .0605 & 3.3672 & .0008 & .0850 & .3228 \\
.0000 & .3055 & .0390 & 7.8418 & .0000 & .2290 & .3820 \\
.9837 & .4071 & .0508 & 8.0209 & .0000 & .3074 & .5068 \\
\hline
\end{tabular}

\section{Conclusion}

This research provides evidence that ethical perception has a positive significance impact on tax compliance behaviour. There is also a significant positive relationship between ethical perception and tax compliance behaviour when moderated by education level. However this significance relationship has been changed from stronger to the weaker position. Although there is a moral imperative that individual should be honest in their tax dealings, it has suggested that ethics differs across individuals and that these differences matter in significant ways for their tax compliance behaviour. The difference in ethics among individuals is due to individuals' ethical propensities, and it can be significantly influenced by culture, family backgrounds and changes in surrounding environments. In a nutshell, each individual has a different set of ethical values. Therefore not all individual taxpayers are tax compliance. Specifically, Inland Revenue Board uses self-assessment system that relies on voluntary compliance by individual taxpayers. Although some of them voluntarily comply, but intentional noncompliance still a serious problem due to others unethical perception. Consequently individual ethical perception has been confirmed to have a relatively more significant verifiable relationship with tax compliance behaviour.

Government should instil individual's ethical value from young, through primary until tertiary education. Besides, government should enhance its administration in various areas such as transparency of government transactions, reduce corruptions and inappropriate revenue spending. Therefore they are more willing to pay tax when they enjoy the benefits of their tax money. Further study can be conducted on this area by looking into other factors such as individuals' financial constraints, religion and perception of equity and fairness. All these factors may influence individuals' ethical perception and their tax compliance behaviour 
The results of this research can assist the Malaysia policy makers have a better understanding on the important of individual taxpayers' ethical perception and their education levels towards tax compliance behaviour. Based on this findings, proper improvements can be made to make sure high compliance in future. In addition, this paper will contribute to the tax literature in Malaysia as the existing data obtained available is limited.

This study attempts to addresses the issues of mixed, contradictory and inconsistent results in previous studies. This research adopted part of the ethical theory and theory of planned behaviour, to looks into how ethical perception of individual taxpayers to be influenced by their education level and therefore further influence their tax compliance behaviour. An important contribution of this study is that it extends the previous literature to predict ethical perception and tax compliance behaviour of individual taxpayers in Peninsular Malaysia.

\section{Acknowledgement}

This research was funded by UTAR Research Fund.

\section{References}

Abdullahi, U. M. (2017). Factors influencing tax compliance behavior among the self-employed in Nigeria (Doctoral dissertation, Universiti Utara Malaysia).

Aiken, L. S., West, S. G., \& Reno, R. R. (1991). Multiple regression: Testing and interpreting interactions. Newbury Park, CA: sage.

Alabede, J. O. (2014). An exploratory analysis of individual taxpayers' compliance behaviour in Nigeria: A study of demographic differences and impact. International Journal of Accounting and Taxation, 2(2), 39-64.

Alasfour, F., Samy, M., and Bampton, R. (2016). The determinants of tax morale and tax compliance: Evidence from Jordan. Advances in Taxation (Advances in Taxation, Vol. 23), Emerald Group Publishing Limited, pp. 125-171.

Alm, J., \& Torgler, B. (2011). Do ethics matter? Tax compliance and morality. Journal of Business Ethics, 101(4), 635-651.

Al-Ttaffi, L. H. A., Bin-Nashwan, S. A., \& Amrah, M. R. (2020). The influence of tax knowledge on tax compliance behaviour: A case of Yemeni individual taxpayers. Journal of Business Management and Accounting, 10(2), 15-30.

Al Zeer, I., Alkhatib, A. A., \& Alshrouf, M. (2019). Determinants of Organisational Commitment of Universities' Employees. International Journal of Academic Research in Accounting, Finance and Management Sciences, 9(1), 136-141.

Ameyaw, B., and Dzaka, D. (2016). Determinants of Tax Evasion: Empirical Evidence from Ghana. Modern Economy, 7, 1653-1664.http://dx.doi.org/10.4236/me.2016.714145

Birch, A., Peters, T., \& Sawyer, A. J. (2003). "New Zealanders" attitudes towards tax evasion: a demographic analysis. New Zealand Journal of Taxation Law and Policy. 9(1), 65.

Blanthorne, C., \& Kaplan, S. (2008). An egocentric model of the relations among the opportunity to underreport, social norms, ethical beliefs, and underreporting behavior. Accounting, Organizations and Society, 33(7-8), 684-703. 
INTERNATIONAL JOURNAL OF ACADEMIC RESEARCH IN ACCOUNTING, FINANCE AND

MANAGEMENT SCIENCES

Vol. 11, No. 1, 2021, E-ISSN: 2225-8329 @ 2021 HRMARS

Cahyonowati, N. (2011). Model moral dan kepatuhan perpajakan: wajib pajak orang pribadi. Jurnal akuntansi dan Auditing Indonesia, 15(2), 161-177. Retrieved from https://journal.uii.ac.id/JAAI/

Chan, C. W., Troutman, C. S., \& O'Bryan, D. (2000). An expanded model of taxpayer compliance: Empirical evidence from the United States and Hong Kong. Journal of International Accounting, Auditing and Taxation, 9(2), 83-103.

Creswell, J. W. (2012). Educational research: Planning, conducting, and evaluating quantitative and qualitative research (4th ed.). Upper Saddle River, NJ: Pearson Education.

Daba, G. (2017). Factors affecting rental income tax payers compliance with tax system: In case of Hawassa city administration. Research Journal of Finance and Accounting, Vol.8, No.7.

Defitri, S. Y., \& Fauziati, P. (2018). The effect of demographic factors and e-filling usage on tax compliance. International Journal of Engineering \& Technology, 7(3.25), 156-158.

Devos, K. (2005). The attitudes of tertiary students on tax evasion and the penalties for tax evasion: A pilot study and demographic analysis. eJTR, 3, 222.

Devos, K. (2008). Tax evasion behaviour and demographic factors: An exploratory study in Australia. Revenue Law Journal, 18(1), 6698.

Eiya, O., Ilaboya, O. J., \& Okoye, A. (2016). Religiosity and tax compliance: Empirical evidence from Nigeria. Igbinedion University Journal of Accounting, 1(1), 27-41.

Ejakait, M. A. (2011). Taxpayer education and tax compliance: an analysis of PAYE from the manufacturing sector in Kenya: A case of Medium Taxpayers Office (Doctoral dissertation).

Eriksen, K., \& Fallan, L. (1996). Tax knowledge and attitudes towards taxation; A report on a quasiexperiment. Journal of economic psychology, 17(3), 387-402.

Etikan, I., Musa, S. A., \& Alkassim, R. S. (2016). Comparison of convenience sampling and purposive sampling. American journal of theoretical and applied statistics, 5(1), 1-4.

Fauziati, P., Minovia, A. F., Muslim, R. Y., \& Nasrah, R. (2016). The impact of tax knowledge on tax compliance case study in Kota Padang, Indonesia. Journal of Advanced Research in Business and Management Studies, 2(1), 22-30.

Frey, B. S. (2009). Punishment and beyond. Center for Research in Economics, Management and the Arts, Switzerland, Working Paper No. 418.

Galib, A., Indrijawati, A., \& Rasyid, S. (2018). The effect of spirituality, subjective norms and perceived behavioral control on taxpayer compliance.Journal of Research in Business and Management, 6(4), 1-7.

Ghani, H. H. A., Abd Hamid, N., Sanusi, S., \& Shamsuddin, R. (2020). The effect of tax knowledge, compliance costs, complexity and morale towards tax compliance among self-employed in Malaysia. Global Business and Management Research, 12(1), 18-32.

Groenland, E. A., Van Veldhoven, G. M. (1983). Tax evasion behaviour: A psychological framework. Journal of Economic Psychology, 3(2), 129-144.

Gupta, R. (2009). An empirical study of demographics of perceptions of tax evasion in New Zealand. Journal of Australian Taxation. 12(1/2), 1- 40.

Harun, R. J., Abu Bakar, M. J., \& Tahir, I. M. (2011). Ethics and tax evasion: Do accounting and business students' opinions differ? International Business and Management, 2(1), 122-128.

Hasseldine, J., Holland, K., and Rijt, P.V. (2009). The management of tax knowledge. The Association of Chartered Certified Accountants, ACCA, London.

Henderson, B. C., \& Kaplan, S. E. (2005). An examination of the role of ethics in tax compliance decision. Journal of the American Taxation Association, 27(1), 39-72. 
INTERNATIONAL JOURNAL OF ACADEMIC RESEARCH IN ACCOUNTING, FINANCE AND

MANAGEMENT SCIENCES

Vol. 11, No. 1, 2021, E-ISSN: 2225-8329 @ 2021 HRMARS

Ho, J. K., Loo, E. C., \& Lim, K. P. (2006). Perspective of non-taxpayers' perception on issues of ethics and equity in tax compliance. Malaysian Accounting Review, 5(2), 47-59.

Ho, D., and Wong, B. (2008), "Issues on compliance and ethics in taxation: what do we know?", Journal of Financial Crime, Vol. 15 No. 4, pp. 369-382.

Ho, D., Ho, D., and Young, A. (2013). A study of the impact of culture on tax compliance in China. International Tax Journal, Vol. 39 No. 3, pp. 33-50.

Hosseini Kondelaji, M., Sameti, M., Amiri, H., \& Moayedfar, R. (2016). Analyzing determinants of tax morale based on social psychology theory: case study of Iran. Iranian Economic Review, 20(4), 581-598.

Jayawardane, D., \& Low, K. (2016). Taxpayer attitude and tax compliance decision in Sri Lanka. International Journal of Arts and Commerce, 5(2), 124.

Kasipillai, J. (1998). Hidden economy and tax investigation: A Malaysian perspective. Tax Nasional, September, 12-17.

Kasipillai, J., Aripin, N., \& Amran, N. A. (2003). The influence of education on tax avoidance and tax evasion. eJTR, 1, 134.

Kasipillai, J., Mat Udin, N., \& Ariffin, Z. Z. (2003). How do moral values influence tax compliance? Findings from a survey. Chartered Secretary Malaysia, June, 10-15.

Kornhauser, M. E. (2007). Normative and cognitive aspects of tax compliance: Literature review and recommendations for IRS regarding individual taxpayers. Florida Tax Review, 8(6), 601-634.

Lago-Peñas, I., \& Lago-Peñas, S. (2010). The determinants of tax morale in comparative perspective: Evidence from European countries. european Journal of Political economy, 26(4), 441-453.

Loo, E. C., McKerchar, M., \& Hansford, A. (2009). Understanding the compliance behavior of Malaysian individual taxpayers using a mixed method approach. Journal of the Australasian Tax Teachers Association, 4(1), 181 - 202.

Loo, E. C., Evans, C., \& McKerchar, M. A. (2012). Challenges in understanding compliance behaviour of taxpayers in Malaysia. Asian Journal of Business and Accounting, 3(2), 2010.

Lumumba, O. M., Migwi, S. W., and Magutu, O. (2010). Taxpayers' attitudes and tax compliance behavior in Kenya: how the taxpayers' attitudes influence compliance behavior among SMEs business income earners. African Journal of Business and Management, Vol. 1, pp. 112-122.

Mangoting, Y., Tangkelobo, H., \& Sina, W. L. (2019). Taxpayer compliance model based on transparency, ethics, and trust (Doctoral dissertation, Petra Christian University).

Marziana H., Mohamad, N., Orkhazimah A., \& Mohmad, S. D. (2010). Perceptions of taxpayers with level of compliance: A comparison in the east coast region, Malaysia. Journal of Global Business and Economics, 1(1), 241-257.

McGee, R. W., \& Ross, A. (2014). Education level and ethical attitude toward tax evasion: A six-country study. Available at SSRN 2410582.

McGraw, K., \& Scholz, J. (1988). Norms, social commitment and citizens' adaptation to new laws. Lawyers on Psychology and Psychologists on Law, Swets and Zeitlinger, Berwyn, PA.

Mohd, R. P., Mohd, R. M., \& Wan, F.B. (2013). The perception of tax payers on tax knowledge and tax education with level of tax compliance: A study the influences of religiosity ASEAN Journal of Economics, Management and Accounting 1(1): 118-129.

Mulugeta, S. (2018). Determinants of tax compliance behavior in presumptive taxation system. The case of Dire Dawa administration. Research Journal of Finance and Accounting Vol.9, No.11. 
INTERNATIONAL JOURNAL OF ACADEMIC RESEARCH IN ACCOUNTING, FINANCE AND

MANAGEMENT SCIENCES

Vol. 11, No. 1, 2021, E-ISSN: 2225-8329 @ 2021 HRMARS

Mustapha, L. O. (2017). Demographic factors and personal income tax compliance in Kaduna state. KASU Journal of Accounting Research and Practice, 6(2).

Noor, W. N. B. W. M., \& Abd Razak, S. N. A. (2019). Potential taxpayers' ethical perception of tax evasion: A preliminary survey. International Journal of Accounting, 4(24), 24-31.

Nsor-Ambala, R. (2016). Evidence for the influence of individual ethical orientation on tax compliance among Ghanaian taxpayers. VVU Journal of Business Research, 1(2), 19-33.

Okon, B. D., \& Israel, O. U. (2020). Tax compliance determinants in self-assessment system (SAS): Empirical evidence from Nigeria. IOSR Journal of Business and Management (IOSR-JBM) Volume 22, Issue 3. Ser. II (March. 2020), PP 33-43

Oladipupo, A. O., \& Obazee, U. (2016). Tax knowledge, penalties and tax compliance in small and medium scale enterprises in Nigeria. IBusiness, 8(1), 1-9.

Pratama, A. (2017). Machiavellianism, tax knowledge, and ethical perceptions of tax avoidance: survey of undergraduate students in West Java, Indonesia. International Journal of Trade and Global Markets, 10(1), 83-90.

Redae, R. B., \& Sekhon, S. (2017). Taxpayers' moral and compliance behavior in Ethiopia: A study of Tigray State. International Journal of Research in Finance and Marketing, 7(4), 109-123.

Roth, J. A., Scholtz, J. T., \& Witte, A. D. (1989). Taxpayer compliance: An agenda for research. Philadelphia. University of Pennsylvania Press.

Salam, M. O. (2019). Public Governance quality and personal income tax compliance: Evidence from Ilorin Metropolis, Kwara state, Nigeria. ICAN Journal of Accounting \& Finance, 8(2), 43-63.

Schuetze, H. J. (2002). Profiles of tax noncompliance among the self-employed in Canada: 1969-1992. Canadian Public Policy. 28(2), 219-238.

Sekaran, U., \& Bougie, R. (2016). Research methods for business: A skill building approach. John Wiley $\&$ Sons.

Shiferaw, N., \& Tesfaye, B. (2020). Determinants of Voluntary Tax Compliance (The Case Category A and B Taxpayers in Dire Dawa Administration). International Journal of Scientific and Research Publications, 10(6), 982-996.

Simmons, R., and Cheng, T. Y. (1996). Citizens' attitudes towards tax evasion in Hong Kong. Asian Review of Accounting, Vol. 4 No. 1, pp. 98-117.

Singh, V. (2013). Tax compliance and ethical decision making: A Malaysian perspective. Petaling Jaya: Longman.

Singh, V. (2013). Veerinder on Malaysian tax theory and practice (2nd ed.). CCH Asia.

Somasundram, N. R. (2003). Tax evasion and tax investigation - a study on tax compliance management. Chartered Secretary Malaysia, July, 20- 24.

Song, Y., \& Yarbrough, T. (1978). Tax ehics and taxpayer attitudes: A survey. Public Administration Review, 38(5), 442-452.

Tehulu, T. A., \& Dinberu, Y. D. (2014). Determinants of tax compliance behavior in Ethiopia: The case of Bahir Dar city taxpayers. Journal of Economics and Sustainable Development, 5(15), 268-280.

The Star Online. (2018). IRB puts 79,786 tax evaders on notice. The Star Online. Retrieved July 1, 2019, from https://www.thestar.com.my/news/nation/2018/11/13/irb-puts-79786-taxevaders-onnotice/.

Torgler, B. (2012). Attitudes toward paying taxes in the USA: an empirical analysis the ethics of tax evasion. In McGee, R. W. W. (Ed.), The ethics of tax evasion: Perspectives in theory and practice. New York: Springer. 
INTERNATIONAL JOURNAL OF ACADEMIC RESEARCH IN ACCOUNTING, FINANCE AND

MANAGEMENT SCIENCES

Vol. 11, No. 1, 2021, E-ISSN: 2225-8329 @ 2021 HRMARS

Torgler, B., Demir, I. C., Macintyre, A., \& Schaffner, M. (2008). Causes and consequences of tax morale: An empirical investigation, Economic Analysis and Policy, 38(2), 313-339.

Torgler, B., \& Murphy, K. (2004). Tax morale in Australia: What shapes it and has it changed over time. J. Austl. Tax'n, 7, 298.

Torgler, B., \& Schaltegger, C. A. (2005). Tax morale and fiscal policy (No. 2005-30). CREMA Working Paper.

Trivedi, V. U., Shehata, M., \& Mestelman, S. (2005). Attitudes, incentives and tax compliance. Canadian Tax Journal, 53(1), 29-61.

Tusubira, F. N., \& Mugarura, J. T. (2020). The Moderating Effect of Corruption on Deterrent and SocioPsychological Factors for Tax Compliance: A Conceptual Model for Small and Medium Enterprises in Uganda. European Journal of Business and Management, 12 (22), 46-57.

Verboon, P., \& Van Dijke, M. (2007). A self-interest analysis of justice and tax compliance: How distributive justice moderates the effect of outcome favorability. Journal of Economic Psychology, 28(6), 704-727.

Wong, R. M. K., \& Lo, A. W. Y. (2015). Can education improve tax compliance? Evidence from different forms of tax education (HKIBS Working Paper Series 074-1415). Retrieved from Lingnan University website: http://commons.In.edu.hk/hkibswp/93

Zeynalova, Z. (2019). The role of education in the formation of tax ethics in Azerbaijan. 5 th International Conference on Lifelong Education and Leadership, Sakarya, Turkey. https://www.iclel.com/ 